Special issue of the International Conference on Computational and Experimental Science and Engineering (ICCESEN 2014)

\title{
Processing, Mechanical and Nuclear Characterization of Boron Carbide Ceramics Consolidated by Spark Plasma Sintering
}

\author{
M. Cengiz ${ }^{a}$, S.C. Ozer ${ }^{a}$, B. BuyuK ${ }^{b}$, A.B. Tugrul ${ }^{b}$, O. Yucel ${ }^{a}$,

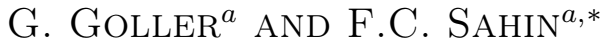 \\ ${ }^{a}$ Istanbul Technical University, Metallurgical and Materials Engineering Department, Istanbul, Turkey \\ ${ }^{b}$ Istanbul Technical University, Energy Institute, Nuclear Researches Division, Istanbul, Turkey \\ Boron carbide $\left(\mathrm{B}_{4} \mathrm{C}\right)$ ceramics were produced by spark plasma sintering technique with 5, 10, 15, and 20 vol.\% \\ aluminum $(\mathrm{Al})$ in order to improve sintering behaviours of $\mathrm{B}_{4} \mathrm{C}$ ceramics. $\mathrm{B}_{4} \mathrm{C}$ ceramics were produced, having \\ square cross-section and $50 \times 50 \times 5 \mathrm{~mm}^{3}$ dimensions. The sintering process was carried out at different temperatures \\ by applying $40 \mathrm{MPa}$ of pressure with $100^{\circ} \mathrm{C} / \mathrm{min}$ under vacuum. The effects of various amounts of $\mathrm{Al}$ additive and \\ sintering temperature on density, vickers hardness, fracture toughness and microstructure were examined. The \\ hardness and fracture toughness of the samples were evaluated by the Vickers indentation technique. Microstruc- \\ tures of the samples were characterized by scanning electron microscopy technique. Fast neutron attenuation \\ properties of the ceramics having highest density were also investigated.
}

DOI: 10.12693/APhysPolA.128.B-187

PACS: 25.20.Dc, 81.20.Ev

\section{Introduction}

$\mathrm{B}_{4} \mathrm{C}$ is evaluated as an ideal material for nuclear applications, especially as control rods in reactors and shielding material in neutron shielding systems, due to its high hardness; being the third hardest material after diamond and cubic boron nitride, high flexural strength, low density, high wear resistance, chemical stability and thermal neutron cross-section value properties $[1,2]$.

In recent years, spark plasma sintering (SPS) technique has been used widely for manufacturing $\mathrm{B}_{4} \mathrm{C}$ and $\mathrm{B}_{4} \mathrm{C}$ containing ceramics because of its improvements on microstructural effects of said materials since it prevents grain coarsening [2]. With applying pulsed direct current, SPS enhances densification and the sintering process is completed at lower temperatures in shorter durations without grain growth compared to the traditional sintering techniques (pressureless sintering, hot pressing and hot isostatic pressing). These attributes make SPS a preferable candidate for producing boron carbide ceramics $[3-5]$.

In this study $\mathrm{B}_{4} \mathrm{C}$ ceramics with $5,10,15$, and 20 vol.\% $\mathrm{Al}$ addition were produced by using SPS method and physical, mechanical and nuclear characterization of those ceramics were performed.

\section{Experimental}

Commercial HS grade $\mathrm{B}_{4} \mathrm{C}$ powders from German H.C. Starck Company, with an average particle size of $0.7 \mu \mathrm{m}$ with $99.5 \%$ purity and metallic Al powder from Alpha

*corresponding author; e-mail: cinar@itu.edu.tr
Aesar Company with an average particle size of $5 \mu \mathrm{m}$ with $99.5 \%$ purity were used in this study. Al additive was used as 5, 10, 15, and $20 \%$ volumetric in this experimental procedure. Suspensions were prepared by mixing $\mathrm{B}_{4} \mathrm{C}$ and $\mathrm{Al}$ powder with $\mathrm{Al}_{2} \mathrm{O}_{3}$ balls in Merck quality ethanol medium by ball milling for $24 \mathrm{~h}$. The slurry was then dried and granulated with screening. After screening, the dry powder was loaded in a graphite die with graphite sheets between the die and the powder for consolidation in SPS.

The samples were sintered by using the SPS apparatus (SPS-7.40MK-VII, SPS Syntex Inc.). After applying initial pressure as $10 \mathrm{MPa}$ manually for compaction before sintering, $100^{\circ} \mathrm{C} / \mathrm{min}$ heating rate was used with $40 \mathrm{MPa}$ pressure from room temperature to sintering temperature. An optical pyrometer was used for measuring the temperature of the die. All of the samples were subjected to 4 min soaking time. Whole process was carried out in vacuum and shrinkage, displacement, temperature, vacuum, current, and voltage for every 1 min was recorded. At the end of the process, sintered $\mathrm{B}_{4} \mathrm{C}$ - $\mathrm{Al}$ compacts were obtained.

After the sintering process, the Archimedes method was used to determine the final densities and relative densities of the compacts. Specimens polished with a diamond paste having particle size of $1 \mu \mathrm{m}$ were subjected to the hardness and fracture toughness tests at room temperature and were evaluated by the Vickers indentation technique at a load of $1 \mathrm{~kg}$. The micrographs of all sample surfaces were observed by scanning electron microscopy (SEM; Model JSM 7000F, JEOL, Tokyo, Japan).

\section{Results and discussion}

Starting powder compositions, sample dimensions, and SPS process parameters along with the relative density 
TABLE I

Density values of $\mathrm{B}_{4} \mathrm{C}$ ceramics with different $\mathrm{Al}$ contents. Dimensions $-50 \times 50 \mathrm{~mm}^{2}$, thickness $5 \mathrm{~mm}$, SPS parameters - $40 \mathrm{MPa}$ and $4 \mathrm{~min}$.

\begin{tabular}{c|c|c}
\hline \hline $\begin{array}{c}\text { Starting } \\
\text { powder }\end{array}$ & $\begin{array}{c}\text { SPS } \\
\text { temperature }\end{array}$ & $\begin{array}{c}\text { Relative } \\
\text { density }\end{array}$ \\
\hline $\mathrm{B}_{4} \mathrm{C}$ & $1550^{\circ} \mathrm{C}$ & 97.9 \\
$\mathrm{~B}_{4} \mathrm{C}+5 \% \mathrm{Al}$ & $1450^{\circ} \mathrm{C}$ & 98.1 \\
$\mathrm{~B}_{4} \mathrm{C}+10 \% \mathrm{Al}$ & $1410^{\circ} \mathrm{C}$ & 97.9 \\
$\mathrm{~B}_{4} \mathrm{C}+15 \% \mathrm{Al}$ & $1410^{\circ} \mathrm{C}$ & 97.9 \\
$\mathrm{~B}_{4} \mathrm{C}+20 \% \mathrm{Al}$ & $1410^{\circ} \mathrm{C}$ & 98.3
\end{tabular}

TABLE II

Hardness and fracture toughness values of $\mathrm{B}_{4} \mathrm{C}$ ceramics with different $\mathrm{Al}$ contents. SPS parameters $-40 \mathrm{MPa}$ and 4 min.

\begin{tabular}{c|c|c|c}
\hline \hline $\begin{array}{c}\text { Starting } \\
\text { powder }\end{array}$ & $\begin{array}{c}\text { SPS } \\
\text { temperature }\end{array}$ & $\begin{array}{c}\text { Hardness } \\
{[\mathrm{GPa}]}\end{array}$ & $\begin{array}{c}\text { Fracture } \\
\text { toughness } \\
{\left[\mathrm{MPa} \mathrm{m}^{1 / 2}\right]}\end{array}$ \\
\hline $\mathrm{B}_{4} \mathrm{C}$ & $1550^{\circ} \mathrm{C}$ & 31.0 & $2.95 \pm 0.3$ \\
$\mathrm{~B}_{4} \mathrm{C}+5 \% \mathrm{Al}$ & $1450^{\circ} \mathrm{C}$ & 29.7 & $3.38 \pm 0.3$ \\
$\mathrm{~B}_{4} \mathrm{C}+10 \% \mathrm{Al}$ & $1410^{\circ} \mathrm{C}$ & 29.6 & $3.73 \pm 0.3$ \\
$\mathrm{~B}_{4} \mathrm{C}+15 \% \mathrm{Al}$ & $1410^{\circ} \mathrm{C}$ & 28.9 & $4.10 \pm 0.3$ \\
$\mathrm{~B}_{4} \mathrm{C}+20 \% \mathrm{Al}$ & $1410^{\circ} \mathrm{C}$ & 28.3 & $4.45 \pm 0.3$
\end{tabular}

values of the samples are given in Table I. All samples have $50 \times 50 \mathrm{~mm}^{2}$ square surface area and $5 \mathrm{~mm}$ thickness. $40 \mathrm{MPa}$ pressure is applied under vacuum and the powders were heated with $100{ }^{\circ} \mathrm{C} / \mathrm{min}$ heating rate and sintered for $4 \mathrm{~min}$. The sintering temperatures were defined by checking the completion of the shrinkage amounts and decreased with increasing $\mathrm{Al}$ content. The reference sample without $\mathrm{Al}$ addition was sintered at $1550{ }^{\circ} \mathrm{C}$ whereas second sample with $5 \% \mathrm{Al}$ addition was sintered at $1450^{\circ} \mathrm{C}$. Other samples were sintered at $1410^{\circ} \mathrm{C}$.

Maximum relative density values were achieved at the temperatures where the shrinkage is completed and the samples are kept constant at that temperature for $4 \mathrm{~min}$. The reference sample $\left(\mathrm{B}_{4} \mathrm{C}\right.$ without $\left.\mathrm{Al}\right)$ have $97.9 \%$ relative density whereas the other samples have higher relative densities. Some samples reached theoretical densities on their centres but since edges and the corners have lower densities, the overall densities of the samples are lower than theoretical density.

The hardness and fracture toughness values of the sintered ceramics are given in Table II. Hardness values of the $\mathrm{B}_{4} \mathrm{C}$ ceramics without $\mathrm{Al}$ addition sintered at $1550^{\circ} \mathrm{C}$ are obtained as $31.0 \mathrm{GPa}, \mathrm{B}_{4} \mathrm{C}$ ceramics with $20 \% \mathrm{Al}$ addition sintered at $1410^{\circ} \mathrm{C}$ are obtained as $28.3 \mathrm{GPa}$. Hardness values decrease slightly with increasing $\mathrm{Al}$ content. The highest fracture toughness value were obtained as $4.45 \pm 0.3 \mathrm{MPa} \mathrm{m}^{1 / 2}$ from the sample with $20 \% \mathrm{Al}$ addition and sintered at $1410^{\circ} \mathrm{C}$ for 4 min, whereas the reference sample has $2.95 \pm 0.3 \mathrm{MPa} \mathrm{m}^{1 / 2}$.
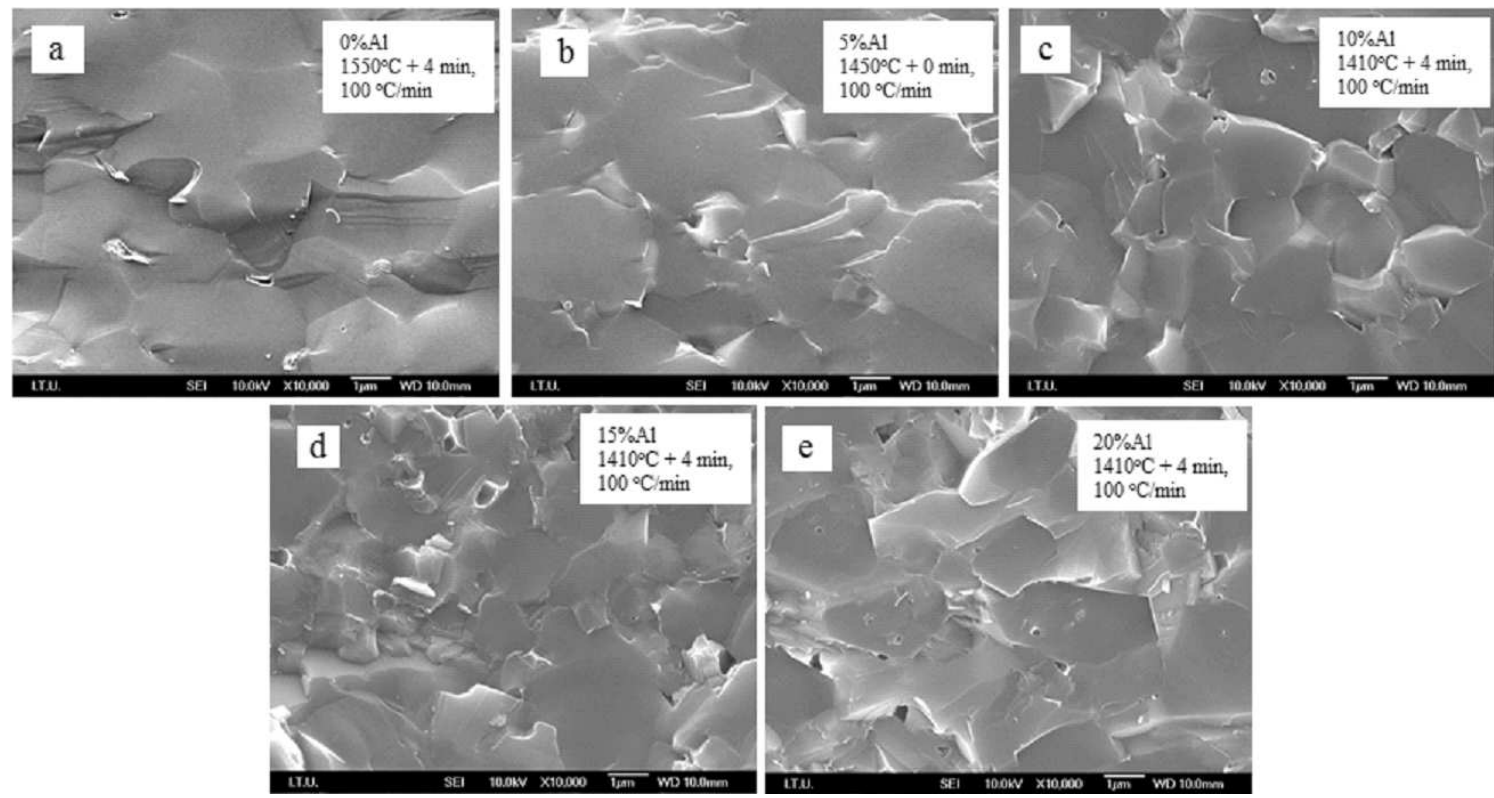

Fig. 1. SEM micrographs of a) $\mathrm{B}_{4} \mathrm{C}$ sintered at $1550^{\circ} \mathrm{C}$, b) $\mathrm{B}_{4} \mathrm{C}$ with $5 \% \mathrm{Al}$ sintered at $\left.1450{ }^{\circ} \mathrm{C}, \mathrm{c}\right) \mathrm{B}{ }_{4} \mathrm{C}$ with $10 \% \mathrm{Al}$ sintered at $1410^{\circ} \mathrm{C}$, d) $\mathrm{B}_{4} \mathrm{C}$ with $15 \% \mathrm{Al}$ sintered at $1410^{\circ} \mathrm{C}$, and e) $\mathrm{B}_{4} \mathrm{C}$ with $20 \% \mathrm{Al}$ sintered at $1410^{\circ} \mathrm{C}$.

Fracture surface SEM images were given in Fig. 1, which provided the best result of relative density values. $\mathrm{B}_{4} \mathrm{C}$ without $\mathrm{Al}$ addition and $\mathrm{B}_{4} \mathrm{C}$ with $5 \% \mathrm{Al}$ addition were observed to have $3-4 \mu \mathrm{m}$ average grain size whereas
$\mathrm{B}_{4} \mathrm{C}$ with 10,15 , and $20 \% \mathrm{Al}$ addition were observed to have $1-2 \mu \mathrm{m}$ average grain size. The difference of the grain sizes between the samples are due to the sintering temperature difference. The sintered ceramics were ob- 
TABLE III The relative count-material thickness values of the $\mathrm{B}_{4} \mathrm{C}-\mathrm{Al}$ composites for $\mathrm{Pu}-\mathrm{Be}$ neutron source.

\begin{tabular}{c|c|c|c|c|c}
\hline \hline \multirow{2}{*}{$x[\mathrm{~cm}]$} & \multicolumn{5}{|c}{ Relative count $\left[/ / I_{0}\right]$} \\
\cline { 2 - 6 } & $\mathrm{B}_{4} \mathrm{C}+$ & $5 \% \mathrm{Al}$ & $10 \% \mathrm{Al}$ & $15 \% \mathrm{Al}$ & $20 \% \mathrm{Al}$ \\
\hline 0 & 1.0000 & 1.0000 & 1.0000 & 1.0000 & 1.0000 \\
0.5 & 0.8544 & 0.8586 & 0.8561 & 0.8838 & 0.8980 \\
1.0 & 0.8198 & 0.8308 & 0.8415 & 0.8445 & 0.8552 \\
1.5 & 0.7727 & 0.8024 & 0.8241 & 0.8246 & 0.8267 \\
2.0 & 0.7336 & 0.7550 & 0.7780 & 0.7782 & 0.7791
\end{tabular}

TABLE IV

Effective removal cross-section and half value layer values of the samples.

\begin{tabular}{c|c|c|c|c}
\hline \hline \multirow{2}{*}{ Material } & \multicolumn{2}{|c|}{$\left.\begin{array}{c}\text { Effective removal } \\
\text { cross-sections [cm }\end{array}{ }^{-1}\right]$} & \multicolumn{2}{c}{$\begin{array}{c}\text { Half value } \\
\text { layers }[\mathrm{cm}]\end{array}$} \\
\cline { 2 - 5 } & $\Sigma_{\text {eff }}$ & Std. dev. & HVL & Std. dev. \\
\hline $\mathrm{B}_{4} \mathrm{C}$ & 0.158 & 0.008 & 4.386 & 0.051 \\
$\mathrm{~B}_{4} \mathrm{C}+5 \% \mathrm{Al}$ & 0.148 & 0.008 & 4.682 & 0.054 \\
$\mathrm{~B}_{4} \mathrm{C}+10 \% \mathrm{Al}$ & 0.136 & 0.010 & 5.095 & 0.073 \\
$\mathrm{~B}_{4} \mathrm{C}+15 \% \mathrm{Al}$ & 0.134 & 0.009 & 5.171 & 0.0671 \\
$\mathrm{~B}_{4} \mathrm{C}+20 \% \mathrm{Al}$ & 0.132 & 0.009 & 5.250 & 0.0681
\end{tabular}

served to have very few to no pores which are equal in size.

The shielding properties of the $\mathrm{B}_{4} \mathrm{C}$ - $\mathrm{Al}$ ceramics were investigated against fast neutrons [6]. Effective removal cross-sections were carried out by using neutron transmission technique. $\mathrm{Pu}-\mathrm{Be}$ neutron howitzer was used as a neutron source with $5 \mathrm{MeV}$ average neutron energy and $1 \times 10^{5} \mathrm{n} \mathrm{cm}^{-2} \mathrm{~s}^{-1}$ neutron flux. The relative countmaterial thickness values were given in Table III. By using the values in Table III, neutron attenuation properties of the materials were drawn and given in Fig. 2 .

The effective removal cross-sections were calculated by fitting the graphs according to Beer-Lambert's formula given below

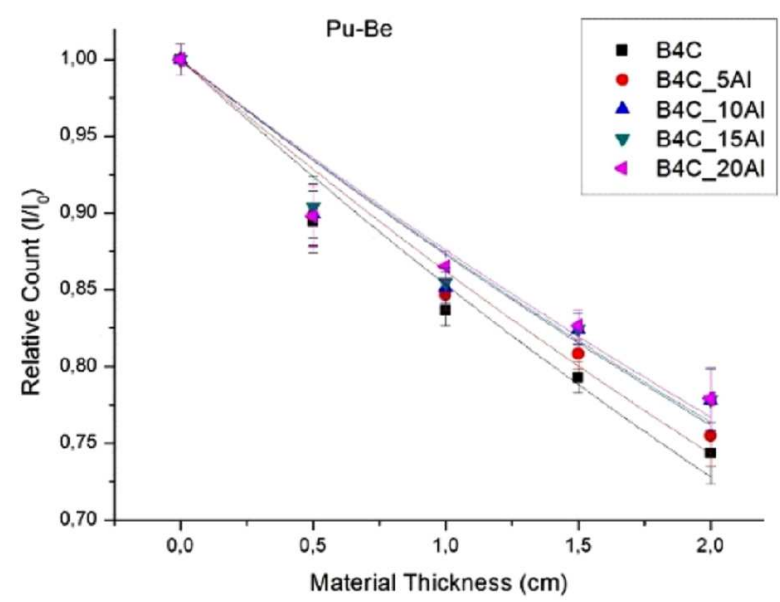

Fig. 2. Relative count-material thickness graphs for $\mathrm{B}_{4} \mathrm{C}-\mathrm{Al}$ composites.

$$
I=I_{0} \mathrm{e}^{\Sigma_{\text {eff }} x},
$$

where $I$ and $I_{0}$ are incoming and initial neutron counts, respectively. $\Sigma_{\text {eff }}$ is effective removal cross-section of the material for the fast neutrons and $x$ is the material thickness. Half value layer values $\left(0.693 / \Sigma_{\text {eff }}\right)$ of the materials for the fast neutrons were calculated. The effective removal cross-sections and half value layers (HVLs) of the $\mathrm{B}_{4} \mathrm{C}-\mathrm{Al}$ ceramics were given in Table IV.

From Table IV it can be seen that the effective removal cross-sections of the $\mathrm{B}_{4} \mathrm{C}-\mathrm{Al}$ composites were decreased with increasing $\mathrm{Al}$ ratio in the composites whereas the HVLs were increased. It means that reinforcing $\mathrm{B}_{4} \mathrm{C}$ with $\mathrm{Al}$ causes a lower fast neutron shielding capability.

\section{Conclusion}

In this study, highly dense $\mathrm{B}_{4} \mathrm{C}$ ceramics with $\mathrm{Al}$ additives and square cross-section were produced by SPS under vacuum with $40 \mathrm{MPa}$ pressure, $100^{\circ} \mathrm{C} / \mathrm{min}$ and different sintering temperatures. Density values higher than $97 \%$ were obtained, theoretical densities were reached locally on the centres of the samples. The Vickers hardness of the samples ranged between 31.0 and $28.3 \mathrm{GPa}$. Fracture toughness values were measured between $2.95 \pm 0.3$ and $4.45 \pm 0.3 \mathrm{MPam}^{1 / 2}$. It is observed that the hardness values and sintering temperatures of the samples are decreased whereas the fracture toughness values increase with increase of $\mathrm{Al}$ addition.

The effective removal cross-section of the $\mathrm{B}_{4} \mathrm{C}-\mathrm{Al}$ ceramics were carried out for $5 \mathrm{MeV}$ average neutrons. The results are compatible with the literature which is calculated as $0.149 \mathrm{~cm}^{-1}$ and 0.126 for $\mathrm{B}_{4} \mathrm{C}$ and $\mathrm{Al}$, respectively. It is concluded that adding $\mathrm{Al}$ to $\mathrm{B}_{4} \mathrm{C}$ decreases the fast neutron shielding property of the samples and that $\mathrm{B}_{4} \mathrm{C}$ has good thermal neutron absorption crosssection (755 barn). Therefore for both thermal and fast neutrons pure $\mathrm{B}_{4} \mathrm{C}$ has higher shielding capability than $\mathrm{B}_{4} \mathrm{C}-\mathrm{Al}$ composites.

\section{Acknowledgments}

The authors express their gratitude to TUBITAK for all kind of support given by 213M163 coded Project.

\section{References}

[1] F. Thévenot, J. Europ. Ceram. Soc. 6, 205 (1990).

[2] H. Lee, R.F. Speyer, J. Am. Ceram. Soc. 86, 1468 (2003).

[3] M. Omori, Mater. Sci. Eng. A 287, 183 (2000).

[4] S. Hayun, S. Kalabukhov, V. Ezersky, M.P. Dariel, N. Frage, Ceram. Int. 36, 451 (2009).

[5] M. Cengiz, B. Yavas, Y. Celik, G. Goller, O. Yucel, F.C. Sahin, Acta Phys. Pol. A 125, 260 (2014).

[6] B. Buyuk, A.B. Tugrul, Ann. Nucl. En. 71, 46 (2014). 